\title{
Humility and Empathy in Emancipatory Politics
}

Philip Yaure

\section{Introduction}

In a recent New York Review of Books essay, Zadie Smith asserts that part of "[w]hat all liberation movements want, surely, is comprehension and compassion."1 Smith points to the epistemic and affective dimensions involved in making political communities more inclusive and securing a robust sense of social justice for their members. Transforming a political community afflicted with oppression into an emancipated one is in large part a matter of cultivating social bonds that reflect our status as free, equal, but mutually dependent, persons. Cultivating such social bonds depends, in large part, on increasing mutual understanding among a community's members and in heightening their sense of commitment to one another.

In her essay, Smith suggests that the tradition of narrative fiction illuminates the epistemic and affective dimensions of emancipatory social bonds. In our engagement with narrative fiction, Smith maintains, we pursue an aspiration to know and be known. Smith casts this aspiration as realized in experiences where we inhabit the perspectives of others: "for years now, in the pages of novels, 'I' have been both adult and child, male and female, black, brown, and white, gay and straight, funny and tragic, liberal and conservative, religious and godless, not to mention alive and dead;" and in which she finds her own perspective inhabited: "I have closed novels and stared at their back covers for a long moment and felt known in a way I cannot honestly say I have felt known by many real-life interactions with human beings, or even by myself." ${ }^{2}$ But the normative standard of knowing and being known, Smith cautions, is not aptly cast in terms of correctness:

\footnotetext{
${ }^{1}$ Zadie Smith, "Fascinated to Presume: In Defense of Fiction," October 24, 2019, https://www.nybooks.com/articles/2019/10/24/zadie-smith-in-defense-of-fiction/. 2 Smith, "Fascinated to Presume."
} 
In my capacity as a writing teacher, I've noticed, in the classroom, the emergence of a belief that fiction can or should be the product of an absolute form of 'correctness.' The student explains that I should believe in her character because this is exactly how X type of person would behave. How does she know? Because, as it happens, she herself is X type of person. Or she knows because she has spent a great deal of time researching $\mathrm{X}$ type of person, and this novel is the consequence of her careful research.... As if fiction could argue itself into a reader's belief system! As if, armed with our collection of facts about what an $\mathrm{X}$ type of person feels, is, and does, always and everywhere, a writer could hope to bypass the intimate judgment of a reader, which happens sentence by sentence, moment by moment.

Smith does not deny that issues of inaccuracy, error, or inauthenticity can arise in our efforts to know and be known. But Smith does deny that knowing and being known is fundamentally a matter of acquiring facts about others and relaying facts about oneself, as if mutual understanding and affective connection were purely a function of how much we know about one another.

The connection Smith draws between the social bonds forged through narrative and the social dimension of emancipatory politics resonates with Black abolitionists' use of autobiography in the US prior to the Civil War. As the editor of one antislavery pamphlet in the 1840s states: "Argument provokes argument... reason is met by sophistry, but the narratives of slaves go right to the hearts of men." In going 'right to the hearts of men,' abolitionists deployed former slaves' narratives to promote comprehension and compassion in white audiences, in ways that they took to be more efficacious than the marshaling of evidence and reasons.

It is tempting to attribute the distinctive emancipatory potential of former slaves' narratives to

\footnotetext{
${ }^{3}$ Boston Chronotype, qtd in William L. Andrews, To Tell a Free Story: The First Century of Afro-American Autobiography, 1769-1865 (Urbana: University of Illinois Press, c1986), 5.
} 
their efficacy in promoting empathic understanding in white audiences. Through detailed, firstpersonal accounts of their experiences, former slaves enabled their audiences to inhabit their perspectives - the sharing of experiences cultivated shared affect and understanding. As Adam Smith puts it, "[s]ympathy... does not arise so much from the view of the passion, as from that of the situation which excites it." Narrative's edge over argument, on this view, is that it supplies audiences with a first-personal perspective to inhabit, in virtue of which these audiences come to know more about the world - in particular, the experience and situation of others situated in the world. On this view, emancipatory social bonds are forged by learning more about one another: we appreciate one another as free, equal, but mutually dependent political actors by feeling what one another feels and understanding one another's interests.

I argue, however, that the emancipatory potential of former slaves' narratives is in fact grounded in a more radical refiguring of the epistemic and affective dimensions of emancipatory politics. By the early 1850s, many Black abolitionists understood the efficacy of such narratives to depend on the ways in which Black authors confronted white readers with their agency and authority over the narrative articulation of their own lives. As Williams Andrews puts it, such narratives involved "a complex discursive encounter presided over by a self-determining narrator who makes free with text and reader in the same of truth to self," rather than truth about self. ${ }^{5}$ As with Zadie Smith, this commitment to truth to self is not a wholesale rejection of the value of accuracy in narrating one's life. But it grounds the emancipatory potential of narrative in the manifestation of the author's agency, rather than in narrative's relaying a correct or 'authentic'

\footnotetext{
${ }^{4}$ Adam Smith, The Theory of Moral Sentiments (London: Printed for A. Millar, 1761), 7. As a terminological note, the 18th and 19th century authors that we will engage with use the term 'sympathy' to refer to the taking up of another person's perspective - what readers today refer to by 'empathy.' There are, of course, important historical nuances in the development of the concept of empathy. My focus in this chapter is to contrast the general epistemic orientation of taking up another's perspective with the general orientation of responding to another person as a fellow agent. Thus, for our purposes, 18th/19th century uses of 'sympathy' and contemporary uses of 'empathy' are interchangeable.

${ }^{5}$ Andrews, To Tell a Free Story, 2 . His emphasis.
} 
perspective for an audience to in inhabit. This manifestation of agency involves a confrontation with one's reader which, as Andrews observes, "was a good deal less solicitous of the white readers's empathy and trust than" narrative strategies that focused on correctness and authenticity. ${ }^{6}$ Instead, this confrontational manifestation of the author's agency aimed to produce, in Andrews words, alienation and disorientation. In other words, I argue, former slaves' narratives confronted white readers with the limits and particularities of their positions. These confrontations, when effective, induced recognition of such limits and particularities — this is to say that these confrontations, when effective, induced humility in white readers. Former slaves' narratives thus illustrate an antislavery politics in which humility is integral to the epistemic and affective dimensions of forging emancipatory social bonds and thereby making political communities more inclusive.

A close examination of former slaves' narratives, and their role in antebellum abolitionism in the US, shows that the knowing and being known of emancipated political life is not, in the first place, a matter of seamlessly taking up one another's feelings and interests; instead, it is a matter of inducing responsiveness to one another's agency — and especially the agency of those who are marginalized in oppressive polities. Bonds of trust, loyalty, solidarity, and non-paternalism (i.e., emancipatory social bonds) are forged primarily through an appreciation of others' agency, rather than others' perspectives (construed as objects one might herself take up and inhabit for a time). This is to say that the knowing and being known of emancipated political life is fundamentally a matter of acknowledgment: practical responsiveness to one another's agency and normative standing. Empathy does play a role on this view - a full appreciation of what someone is doing depends on an understanding of her perspective on the world - but it is ancillary to humble acknowledgment of others' agency. Acknowledgment, especially in contexts in which privileged

\footnotetext{
${ }^{6}$ Andrews, 2. 'Authenticity,' in this context, means that the source of the narrative is its purported author, who in fact speaks from the social position which she purports to.
} 
political actors must respond to the agency of marginalized political actors, is the epistemic and affective mechanism through which communities reforge themselves more inclusively.

In this paper, I defend the role of humility and acknowledgment in the epistemic and affective dimensions of emancipatory politics by developing the relationship between narrative and political judgment. Political judgment, through which persons decide what courses of action to adopt, with whom they should act, and what risks to take, is one prominent social aspect of political life: we always exercise political judgment in relation to other persons, and thus political judgment is always a locus through which social bonds can be forged or compromised. Political judgment helps to forge emancipatory social bonds when it is responsive to others' agency - this is an integral part of what it is for political judgment to be responsible. Where political actors - especially privileged political actors exercising judgment in relation to marginalized political actors - exercise political judgment primarily on the basis of empathy, emphasizing their capacity to inhabit correct and authentic perspectives of the oppressed, they tend to exercise political judgment irresponsibly — in ways that fail to respond to the agency of marginalized political actors. But where political actors exercise political judgment primarily on the basis of humility, emphasizing a recognition of their limits and particularities in relation to those with whom they act in concert, they tend to exercise political judgment responsibly — in ways that respond to the agency of marginalized political actors. ${ }^{7}$ These claims, I show, are exemplified in antebellum abolitionism in the US, particularly in relation to former slaves' narratives.

In section 2, I characterize what I mean by responsibility in political judgment. In section 3, I sketch a picture on which cultivating empathy might seem to contribute responsible political judgment. In section 4, I challenge this picture by showing how former slaves' narratives were

\footnotetext{
${ }^{7}$ This implies that responsible political judgment is integral to the kind of activity that Arendt takes as constitutive of political life, action in concert. Arendt, Hannah. The Human Condition. Chicago: University of Chicago Press, 1998.
} 
used by white abolitionists to ground political judgments that were not responsible to free and enslaved Black Americans; in such cases these narratives were drawn on primarily in terms of inducing empathy. In section 5, I show that Black abolitionists, by the 1850 s, drew on former slaves' narratives to induce humility in white audiences, in order to render the latter's political judgment more responsible. In section 6 , I explicate the connection between acknowledgmentpractical responsiveness to others' agency — and emancipatory social bonds.

\section{Responsible Political Judgment}

Political judgment - through which we decide what values or aims to prioritize, how to act in pursuit of such aims, and with whom to act- is one locus where the epistemic and affective dimensions of political life manifest (i.e., those which concern how we understand and feel one another as fellow members of a community), and where emancipatory social bonds are forged. Frederick Douglass captures the connection between political judgment and emancipatory social bonds in his discussion of a Sabbath school he helped to organize as slave on the plantation of William Freeland in eastern Maryland in 1835, in which he and other slaves taught one another to read. He describes the bonds forged between the participants in the Sabbath school in this way: "I never loved, esteemed, or confided in men, more than I did in these. They were true as steel, and no band of brothers could have been more loving. There were no mean advantages taken of each other, as is sometimes the case where slaves are situated as we were; no tattling; no giving each other bad names to Mr. Freeland; and no elevating one at the expense of the other." 8 The participants in the Sabbath school forge bonds of love, trust, loyalty, solidarity, and nonpaternalism with one another. Crucially, Douglass emphasizes that these bonds manifest in the ways in which participants in the Sabbath school decide to act on matters that concern them collectively: "We never undertook to do any thing, of any importance, which was likely to affect

\footnotetext{
${ }^{8}$ Frederick Douglass, My Bondage and My Freedom (Urbana: University of Illinois Press, 1987), 165.
} 
each other, without mutual consultation. We were generally a unit, and moved together."9 The Sabbath school participants acted as a unit — in ways that reflected commitments of trust, loyalty, solidarity, and non-paternalism — in forming judgments on the basis of mutual consultation. In other words, in exercising political judgment well — in ways that reflect each actor's agency and effectively coordinates among them - consists in judging in ways that enact bonds of trust, loyalty, solidarity, and non-paternalism.

Good political judgment is guided by two sorts of normative considerations. First, good political judgment is guided by a set of ultimate ends or principles: we have some idea of the kind of world we are trying to bring about, or the concrete change in the world we are trying to effect. Second, good political judgment is responsible to the world and other political actors: we take into account the likely and potential outcomes of a course of action, and how the character and execution of a course of action depends on others' judgment and agency.

These two sets of normative considerations correspond, at least roughly, to what Max Weber calls an "ethic of ultimate ends" and an "ethic of responsibility." ${ }^{10}$ For our purposes, what matters is that an integral part of good political judgment is an appreciation of how political action depends on others as fellow agents, without whom the action cannot be performed, and whose judgment and activity will shape the exact character of the action and its effects. Weber captures this point in "Politics as a Vocation" in his discussion of a "committed syndicalist" calling for a strike. The syndicalist, in Weber's example, is confronted with the fact that this particular strike, in this particular circumstance, is likely to "result in increasing the opportunities of reaction, in increasing the oppression of [her] class, and obstructing its assent." ${ }^{11}$ In response

\footnotetext{
${ }^{9}$ Douglass, 165.

${ }^{10}$ Max Weber, "Politics as a Vocation," in From Max Weber: Essays in Sociology, ed. H.H. Gerth and C. Wright Mills (New York: Oxford University Press, 1946), 77-128. Nothing central to my argument hangs on whether this gloss of good political judgment captures Weber's discussion of the ethic of ultimate ends and the ethic of responsibility exactly. I take this to be an intuitive picture of good political judgment that echoed in Weber's own discussion. ${ }^{11}$ Weber, 121.
} 
to this fact the syndicalist responds that ““'[i]f an action of good intent leads to bad results, then, in the actor's eyes, not [she] but the world, or the stupidity of other men, or God's will who made them thus, is responsible for the evil." ${ }^{12}$ She fails to act according to an ethic of responsibility because she fails to fully acknowledge that the course of action she calls for, and the end she wills, depends - both in its achievement and specific character - on the agency of others. What acknowledgment we do find in her reaction expresses contempt: for her fellows too 'stupid' to act in their ultimate interests, for a world unconducive to end she aims to bring about, and perhaps even the very fact that what she wills in political life depends on the world and on others.

In claiming that responsible political judgment is attuned to the limits of political actors, Weber is not, I think, expressing a crude pessimism about the possibilities of political action. After all, Weber concludes that the person who has the calling for politics is one who persists in advancing her political ideals in spite of a world that sometimes appears to her as "too stupid or too base. ${ }^{.13}$ Complex (and sometimes irresolute) political actors acting in a complex (and sometimes irrational) world will inevitably frustrate political ideals. The political actor whose judgment is informed by an ethic of responsibility acknowledges the ways in which the world might frustrate her judgment, and nevertheless resolves to stand by her judgment. I think we should read Weber as suggesting that one can stand by her political judgment responsibly only if she acknowledges the ways in which the world (and other political actors) might frustrate her judgment. For instance, the politically responsible syndicalist might, in the face of risks to her cause, nevertheless call for a strike; but she will do so while acknowledging that the aim of her judgment might be frustrated (for instance) by workers who must balance their aspirations for emancipation with their need to sustain their families. The politically responsible syndicalist is

\footnotetext{
${ }^{12}$ Weber, 121.

${ }^{13}$ Weber, 128.
} 
able to look her fellow workers in the eye, acknowledge the risk they will undertake together, and nevertheless stand resolute in the course of action she calls for.

Thus, if political judgment must be responsible in order to be good, and if responsible political judgment is responsive to the political agency of other persons, then good political actors must cultivate and maintain an appreciation of the political agency of other persons. ${ }^{14}$ Appreciating others' agency involves both an understanding of their experiences and preferences, and recognition the fact that they are agents with the capacity to act with others in pursuit of preferences in light of their experiences. In other words, forging the epistemic and affective dimensions of political communities with emancipatory potential (i.e., those whose members relate on the basis of bonds of trust, loyalty, solidarity, and non-paternalism) depends on cultivating both empathetic understanding of one another's perspectives and humble recognition of one another's agency. Responsible political judgment is an expression of, and itself reinforces, emancipatory social bonds among the agents who exercise such judgment in relation to one another. ${ }^{15}$ Part of living well together is judging in ways responsible to one another.

How we exercise political judgment responsibly in relation to one another is an especially urgent question for political actors engaged in emancipatory politics - that is, political actors seeking to combat forms of oppression in communities in which they are situated. Such actors aim, in part, to forge emancipatory social bonds among members of their communities, which

\footnotetext{
${ }^{14}$ I should underscore that the main argument of this chapter depends only on this conditional claim. My primary aim is to demonstrate that political judgment is not made responsible by cultivating empathetic understanding of others' interests and capacities; political judgment is instead made responsible through acknowledgment of one another as free, equal, but mutually dependent political actors. It is still possible, for all that I say in this section, for someone to reject responsibility as an aspect of good political judgment in order to preserve an integral role for empathy. The remarks in the following paragraphs are meant to make plausible the idea that responsibility is an aspect of good political judgment, but all one needs to accept for the main thesis of this chapter is the conditional claim: if good political judgment is responsible, then empathy without humility cannot make our political judgment good.

${ }^{15}$ This implies that understanding how political actors exercise political judgment responsibly both captures (1) one aspect of what it is to live in a political community grounded in relations of trust, loyalty, solidarity, and nonpaternalism, and (2) one way in which political actors can themselves act to forge such communities.
} 
involves exercising political judgment well. ${ }^{16}$ But in communities afflicted by oppression, it is especially challenging to forge such bonds: conditions of oppression inhibit our ability to understand, rely on, and act in concert with one another, instead disposing us to act in ways that reinforce hierarchies of race, class, gender, sexuality, and ability (among others). Thus, those engaged in emancipatory politics need a particularly robust story about how to cultivate the bonds of love, trust, loyalty, solidarity, and non-paternalism through which we know and are known in community with one another. Part of this robust story involves explaining how we exercise political judgment well — and thus how we exercise it responsibly — in relation to one another.

One important part of this story concerns how privileged political actors exercise political judgment responsibly in relation to marginalized political actors. Political actors in positions of privilege (i.e., those who are not subject to, and perhaps benefit from, particular forms of oppression) are especially likely to have attenuated epistemic and affective connections to marginalized political actors, precisely because of the oppressive social structures in which they are embedded. So it's especially (although by no means exclusively!) important to understand how privileged political actors can exercise political judgment in ways that reflect the free, equal, but mutually dependent status of marginalized political actors: what it means for privileged political actors to know marginalized political actors, and what it means for marginalized political actors to be known, in ways that express the free, equal, and mutually dependent status of all. ${ }^{17}$

\footnotetext{
${ }^{16}$ This is for both instrumental and constitutive reasons. Political actors who relate to one another on terms of trust, loyalty, solidarity, and non-paternalism are able to act effectively in relation to one another; to 'move together as a unit,' as Douglass observes. But emancipated political life itself also consists, in part, in standing in relations that reflect our status as free, equal, but mutually dependent members of a shared community. ${ }^{17}$ This formulation itself gestures to part of the challenge: characterizing the role of privileged political actors as knowing and the role of marginalized political actors as being known suggests that there is something for the former to do and the latter to be subject to. However, as will become clear in the way in which I develop humility as an integral attitude to exercising political judgment responsibly, the picture I endorse centers the political agency of marginalized political actors, not as objects of understanding for privileged political actors, but as fellow agents to whom privileged actors must be fully responsive in their judgment.
} 
In order to exercise political judgment in ways that are responsible to marginalized political actors, privileged political actors must cultivate an appreciation of the former's agency. This appreciation involves both an understanding of marginalized political actors' experiences and interests, and recognition of their agential capacities. But there are two different ways of characterizing the cultivation of such understanding. On the first, cultivating such understanding is a matter of learning more about others - the knowing and being known of emancipated political life is a matter of knowing the facts about others' experiences, interests, and capacities, and having others know such things about oneself. This approach to cultivating appreciation of others' agency is expressed in a strong emphasis on the role of empathy: we draw on facts about others' experiences, interests, and feelings in order to imaginatively inhabit their perspectives. We appreciate others' agency from the inside, on this picture.

On the second, cultivating such understanding is a matter of being responsive to others - the knowing and being known of emancipated political life is a matter of acknowledging (i.e., being responsive to) others' experiences, interests, and capacities, and having others acknowledge such things in relation to oneself. This approach to cultivating appreciation of others' agency is expressed in a strong emphasis on the role of humility: through recognition of the particularities and limits (epistemic, affective, and agential) of our own social position and agency, we orient ourselves to others as free, equal, but mutually dependent persons who act in concert with others in pursuit of interests. We appreciate others' agency from the outside, on this picture.

\section{The Case for Empathy}

Antebellum abolitionists saw part of their project in terms of addressing an epistemic and affective gap between white Americans and Black Americans. In particular, abolitionists thought that advancing the aims of antislavery was dependent on addressing white Americans' failure to appreciate the situation of Black Americans under conditions of slavery and white supremacy. 
William Lloyd Garrison describes this condition of white Americans in the introduction to Frederick Douglass's first autobiography, Narrative of the Life of Frederick Douglass:

So profoundly ignorant of the nature of slavery are many persons, that they are stubbornly incredulous whenever they read or listen to any recital of the cruelties which are daily inflicted on its victims. They do not deny that the slaves are held as property; but that terrible fact seems to convey to their minds no idea of injustice, exposure to outrage, or savage barbarity. Tell them of cruel scourgings, of mutilations and brandings, of scenes of pollution and blood, of the banishment of all light and knowledge, and they affect to be greatly indignant at such enormous exaggerations, such wholesale misstatements, such abominable libels on the character of the southern planters! As if all these direful outrages were not the natural results of slavery! As if it were less cruel to reduce a human being to the condition of a thing, than to give him a severe flagellation, or to deprive him of necessary food and clothing! As if whips, chains, thumb-screws, paddles, bloodhounds, overseers, drivers, patrols, were not all indispensable to keep the slaves down, and to give protection to their ruthless oppressors! As if, when the marriage institution is abolished, concubinage, adultery, and incest, must not necessarily abound; when all the rights of humanity are annihilated, any barrier remains to protect the victim from the fury of the spoiler; when absolute power is assumed over life and liberty, it will not be wielded with destructive sway! Skeptics of this character abound in society. In some few instances, their incredulity arises from a want of reflection; but, generally, it indicates a hatred of the light, a desire to shield slavery from the assaults of its foes, a contempt of the colored race, whether bond or free. ${ }^{18}$

The profound ignorance of white Americans, on Garrison's characterization, is a matter not only ${ }^{18}$ Frederick Douglass, Narrative of the Life of Frederick Douglass, 1845, x-xi. 
of empirical ignorance of the material conditions to which enslaved Black people in the US are subjected, but also insensitivity to the moral character of these conditions. White Americans fail to understand the forms of violence to which enslaved Black people are subjected, and even when they possess some factual understanding of the conditions of slavery, they fail to appreciate the cruelty and brutality of these conditions. Garrison describes white Americans' empirical and moral ignorance of slavery as a matter of incredulity and skepticism: when confronted with the empirical and moral character of slavery, they cast doubt on these facts, either rejecting the empirical descriptions outright or obscuring their moral horror by insisting that these conditions are 'natural,' or that those who are subjected to them are property rather than persons. In essence, Garrison sees one important challenge for the antislavery movement to address as combatting white ignorance, which he understands as an epistemic and affective gap between white Americans' understanding of the empirical and moral character of slavery and the empirical and moral facts as they are. ${ }^{19}$

Martin Delany similarly identifies an epistemic and affective gap between the conditions of slavery and the understanding of white Americans. In The Condition, Elevation, Emigration, and Destiny of the Colored People of the United States, he observes:

One part of the American people, though living in near proximity and together, are quite unacquainted with the other; and one of the great objects of the author is, to make each acquainted. Except the character of an individual is known, there can be no just appreciation of his worth; and as with individuals, so it is with classes. ${ }^{20}$

Delany here emphasizes that white Americans are not only ignorant of the empirical and moral

\footnotetext{
${ }^{19}$ Linda Martín Alcoff, "Epistemologies of Ignorance: Three Types," in Race and Epistemologies of Ignorance, ed. Nancy Tuana and Shannon Sullivan (Albany: State University of New York Press, 2007), 39-58; Charles Mills, "White Ignorance," in Race and Epistemologies of Ignorance, ed. Nancy Tuana and Shannon Sullivan (Albany: State University of New York Press, 2007), 11-38.

${ }^{20}$ Martin Delany, The Condition, Elevation, Emigration, and Destiny of the Colored People of the United States (Bensenville: Lushena Books, 2014), 9.
} 
character of slavery, but the character of Black Americans subjected to it. He envisions one of the aims of his pamphlet as addressing this ignorance, attuning white Americans to the character of enslaved and free Black Americans, and their contributions to the nation. ${ }^{21}$

Delany observes, moreover, that this ignorance afflicts not only white Americans actively or passively implicated in the maintenance of slavery, but also those actively involved in the antislavery cause:

The colored people are not yet known, even to their most professed friends among the white Americans; for the reason, that politicians, religionists, colonizationists, and abolitionists, have each and all, at different times, presumed to think for, dictate to, and know better what suited colored people, than they knew for themselves; and consequently, there has been no other knowledge of them obtained, than that which has been obtained through these mediums. ${ }^{22}$

Delany emphasizes that white Americans' ignorance affects the political judgments they make on issues concerning the situation of enslaved and free Black Americans - this applies not only to politicians, religious figures, and proponents of colonization, but even abolitionists. White abolitionists exercise political judgment in a paternalistic fashion: they take themselves to know better "what suited colored people." By exercising judgment in this way, white abolitionists failed to judge in ways responsive to the political agency of enslaved and free Black people. Ironically, this presumption is grounded, on Delany's view, precisely in white abolitionists' ignorance of Black Americans' situation and character.

This is precisely what we find in, for instance, Gerrit Smith's "Address to the Slaves of the

\footnotetext{
${ }^{21}$ Ultimately, Delany is pessimistic about the viability of this project. In Chapter 16 of the pamphlet, Delany shows that white Americans have been utterly unresponsive to the manifest contributions and character of Black Americans, as illustrated through the enactment of the 1850 Fugitive Slave Act. In light of this, Delany calls for an emigrationist antislavery strategy. But this emigrationist strategy is premised in part, for Delany, on the non-viability of addressing white Americans' ignorance and unresponsiveness.

${ }^{22}$ Delany, The Condition, Elevation, Emigration, and Destiny of the Colored People of the United States, 9.
} 
United States," given at the 1842 Convention of Liberty Party Abolitionists and published in the National Anti-Slavery Standard. ${ }^{23}$ At first, Smith seems to articulate a promising approach for abolitionists. He criticizes strategies that have abolitionists focus on persuading slaveholders:

Why do abolitionists concede, that their labors for the slave must be expended directly upon his master; and that they are to seek to improve the condition of the one, only through favorable changes wrought in the mind of the other? ${ }^{24}$

Instead, Smith maintains that an effective abolitionist strategy organizes directly in support of slaves' resistance efforts:

Let abolitionists fully and solemnly utter the doctrine, that they are bound to enter into and maintain all practicable communications with the slave; and the candid and intelligent will not only respond to it, but, ere they are aware, they will have been carried along, by its trains of consequences and influences, to the conviction, that the abolitionist has a perfect moral right to go into the South, and use his intelligence to promote the escape of ignorant and imbruted slaves from their prison-house.

Smith's emphasis on the importance of 'practicable communications' reflects, in part, white abolitionists' commitment that effective antislavery organizing requires an empathic appreciation of the situations and perspectives of enslaved Black people, so that abolitionists efforts are guided in ways that support the agency of slaves. But while Smith advocates for antislavery strategies which support the agency of slaves, his characterization of slaves as "ignorant and imbruted" ought to give us pause. This characterization is directly linked to Smith's conception of how white abolitionists ought to support the political agency of slaves: the white abolitionist ought to "use his intelligence to promote the escape" of slaves. This line suggests that the white abolitionist's intervention is to supplement a lack of political agency on the part of slaves who

\footnotetext{
${ }^{23}$ The newspaper of the American Anti-Slavery Society.

${ }^{24}$ Gerrit Smith, "Address to the Slaves of the United States, by the Convention of the Liberty Party Abolitionists," National Anti-Slavery Standard, February 24, 1842.
} 
are incapable of organizing adequate antislavery resistance in the absence of the support of abolitionists.

This attitude towards slaves as persons lacking a fully developed political agency is underscored in the remarks Smith makes directed to "the colored people of the South" in his address. He urges slaves "against violent attempts to recover your freedom" while "call[ing] on every slave, who has the reasonable prospect of being able to run away from slavery, to make the experiment." In the course of such escapes, moreover, Smith— speaking for the "we" of white abolitionists - "entreat you not to steal," although he says that this does not "forbid your innocent yieldings to necessity."

Even if one endorses the principles that Smith articulates in his address (either as morally appropriate or politically prudent), I think we should be troubled by the conception of political relations between white abolitionists and slaves Smith enacts. Smith hopes that the address will make its way into the hands of some enslaved people in the south, as he remarks in the address that "we shall get as many copies of this address as we can, into the hands of your white friends in the slave States. To these, as also to the few (alas! How few!) of the colored people of the South who, some by permission, and some by stealth, have obtained the art of reading, we look to acquaint you with its contents." But, from the content of his address, it is clear that what Smith hopes will make it to the ears of his envisioned audience are instructions about how slaves ought to comport themselves in pursuit of freedom. The apparent function of white abolitionists, as embodied in Smith's address, is to exercise responsible political judgment on behalf of slaves, and thereby discipline slaves' conduct in pursuit of freedom. While Smith's political judgment is responsive to Weber's ethic of responsibility — as Smith is advocating for and against courses of action in light of their potential consequences - the disciplinary relationship that Smith embodies in relation to the slaves he addresses reproduces a racist hierarchy in his abolitionist 
politics: it is white abolitionists who are best situated to judge what forms of antislavery resistance are appropriate and most effective, on behalf of Black slaves engaged in such resistance.

Moreover, while Smith directs his "Address" to slaves in the South, his immediate audience is a group of (predominately white) abolitionists at the Liberty Party Convention. The primary message for Smith's immediate audience doesn't concern the content of Smith's instructionshis audience at the Convention will not be conducting escape attempts themselves-but rather the political relationship between abolitionists and slaves that Smith's instructions enact. For Smith's immediate audience, the primary claim is that abolitionists ought, like Smith in this address, make responsible political judgments on behalf of slaves engaged in resistance, and try to bring the conduct of resisting slaves in line with their judgment. What is most salient for Smith's immediate audience is the political relationship that his address models, rather than the specific instructions it provides. ${ }^{25}$

The attitude Smith takes towards enslaved Black people engaged in antislavery resistance is an instance of what Martin Delany identifies as the cause of abolitionist organizations' inefficacy in advancing the aims of the antislavery movement:"We [i.e., enslaved and free Black people in the US] are... still occupying a miserable position in the community, wherever we live." ${ }^{26} \mathrm{In}$ diagnosing the inefficacy of abolitionist organizations in advancing the aims of anti-slavery, Delany describes white abolitionists as motivated not only by a desire to eliminate the institution of slavery, but also by an earnest belief in that they have incurred "bounden duty to make full amends for the injustice thus inflicted on an unoffending people. ${ }^{.27}$ But in spite of the laudable

\footnotetext{
${ }^{25}$ I argue in "Deliberation and Emancipation: Some Critical Remarks" that Douglass similarly uses his Fifth of July speech to model a mode of political relation. The primary message for his immediate audience, again a group of predominately white abolitionists, is not that he is a member of their moral and political community, but rather that they ought to relate to Douglass through the perception of this plain fact (instead of by inferring it on the basis of marks and features evidence.)

${ }^{26}$ Delany, The Condition, Elevation, Emigration, and Destiny of the Colored People of the United States, 28.

${ }^{27}$ Delany, 23.
} 
intentions of these abolitionists, Delany urges his audience to examine "our condition even amongst our Anti-Slavery friends. ${ }^{28}$ Such an examination, Delany claims, reveals that:

[W]e find ourselves occupying the very same position in relation to our Anti-Slavery friends, as we do in relation to the pro-slavery part of the community - a mere secondary, underling position, in all our relations to them, and any thing more than this, is not a matter of course affair - it comes not by established anti-slavery custom or right, but like that which emanates from the proslavery portion of the community, by mere sufferance. ${ }^{29}$

Moreover, Delany observes, while white abolitionists affirm the principle "that the colored people were susceptible of all that the whites were, and that all was required was to give them a fair opportunity, and they would prove their capacity," nevertheless in practice it is "urged that colored men are incapable as yet to fill" positions of authority in abolitionist organizations. Such claims, Delany maintains, reveal "that the cause has fallen short" in its emancipatory aspirations, because abolitionist organizations reproduce the very forms of racial oppression and racist ideology that they seek to combat. ${ }^{30}$ This reproduction of racist hierarchies in the abolitionist movement manifests in political judgments like Smith's that fail to appreciate the agency of enslaved and free Black political actors resisting slavery.

Both the aim and the efficacy of the antislavery movement, in the eyes of abolitionists themselves, depended in part on rendering the political judgment of white Americans (both those already invested in the abolitionist movement and those not) responsive to the agency of enslaved and free Black Americans. Both Black and white abolitionists identified one root cause of white Americans' irresponsible political judgment as an epistemic and affective gap between the empirical and moral character of slavery and white Americans' understanding of it.

Many abolitionists understood the bridging of this epistemic and affective gap - of

\footnotetext{
${ }^{28}$ Delany, 24.

${ }^{29}$ Delany, 26.

${ }^{30}$ Delany, 26.
} 
cultivating emancipatory conditions of knowing and being known — in terms of privileged political actors learning more facts about the situation and agency of marginalized persons. Indeed, Delany himself adopts this model in Condition, providing a hundred pages of examples of Black Americans' contributions to the polity as evidence of their political agency and claim to citizenship. But, as Garrison and Delany themselves observe, the enumeration of facts per se was often ineffective in bridging this epistemic and affective gap, because of the skeptical recalcitrance of white people: they would discount empirical evidence and obscure the moral character of slavery. A more robust intervention was required to address the robust forms of white ignorance that rendered white abolitionists' judgments irresponsible to the agency of Black political actors.

For many abolitionists, this more robust intervention depended on narrative- especially narratives of former slaves' lives - to articulate a perspective for white readers to inhabit. Douglass himself adopts this strategy in his first autobiography, Narrative of the Life of Frederick Douglass. Douglass himself identifies the epistemic and affective gap Garrison and Delany describe in connection with his experience after having escaped slavery:

The motto which I adopted when I started from slavery was this-- 'Trust no man!' I saw in every white man an enemy, and in almost every colored man a cause for distrust. It was a most painful situation; and, to understand it, one must needs experience it, or imagine himself in similar circumstances. ${ }^{31}$

Here Douglass urges that white readers can only appreciate his experience of distrust by — if not experiencing themselves - imaginatively projecting themselves into his circumstances.

Douglass's Narrative itself is meant to ground such imaginative projection, as William Andrews observes:

In this statement Douglass, for the first time in Afro-American autobiography, declared

${ }^{31}$ Douglass, Narrative of the Life of Frederick Douglass, 144. 
a new and crucial role for the imagination as a mode of mediation, not distortion and deception, in black-white discourse. He was pointing toward an unprecedented answer to the central rhetorical problem of the slave narrative-- how to build a bridge of sympathetic identification between the diametrical viewpoints of the northern white reader and the southern black fugitive. In the passage under consideration here, Douglass implies that such a bridge could not be extended from the pilings of fact set down by the black narrator. It had to be suspended from imaginative supports that connected each opposing shore of the discourse. That is, Douglass was calling for a genuine discursive relationship of equals in the slave narrative, one based on an active, flexible engagement of the white reader with the black text free from preconceived roles, instituted agendas, and programmed responses. As long as the black narrator played the suppliant role of purveyor of facts for the consumption of the preeminent reader, full appreciation and understanding of the slave narrative could not be attained. Imaginative self-projection of the reader into the text had to be the basic preparatory condition for the kind of understanding that Douglass wanted whites to derive form his story, the understanding of the individual emotional significance of the facts of a fugitive slave's life. ${ }^{32}$

On Andrews' reading of the Narrative, Douglass sees his first-person narrative articulation of his experiences as providing a narrative perspective for white readers to inhabit by imaginatively projecting themselves into Douglass's situation. This imaginative projection provides readers with an empirical and affective understanding of Douglass's life as a fugitive slave which, Andrews claims, puts readers in a 'genuine discursive relationship' with Douglass as author of his life's narrative. Imaginative projection is thus cast as a mode of appreciating Douglass's moral and political agency, as an author whose perspective on his own life articulates the

\footnotetext{
${ }^{32}$ Andrews, To Tell a Free Story, 137. My emphasis
} 
empirical and moral character of his situation in pursuit of aims to which his readers ought to be responsive (as fellow members of his political community).

This picture, on which privileged political actors' imaginative projection into the situation of marginalized persons bridges the epistemic and affective gap in ways that cultivate appreciation of the latter's agency, takes on full realization in Harriet Beecher Stowe's Uncle Tom 's Cabin (1852). In the preface to her novel, Stowe asserts that "[t]he poet, the painter, and the artist, now seek out and embellish the common and gentler humanities of life, and, under the allurements of fiction, breathe a humanizing and subduing influence, favorable to the development of the great principles of Christian brotherhood." ${ }^{33}$ In the context of the antebellum US, Stowe sees authors (both novelists and former slaves recounting their lives) as exerting a humanizing influence on whites through imaginative projection: "The object of these sketches is to awaken sympathy and feeling for the African race, as they exist among us; to show their wrongs and sorrows, under a system so necessarily cruel and unjust as to defeat and do away the good effects of all that can be attempted for them, by their best friends, under it." ${ }^{34}$ Stowe casts Uncle Tom's Cabin, through its rich narrative details, as laying the groundwork for white readers' imaginative projection into the lives of the enslaved Black people she writes about. By inhabiting this perspective, Stowe believes, white readers will be brought to appreciate that the conditions of slavery are incompatible with enslaved Black people's standing as free, equal, but mutually dependent persons, and thus brought to affirm antislavery in a way responsive to the agency of Black Americans.

The general picture, then, is as follows: by supplying the empirical and moral facts of slavery in a way that enables white readers to imaginatively project into the position of enslaved and free Black people, these narratives aimed to render whites people's political judgment responsive to

\footnotetext{
${ }^{33}$ Harriet Beecher Stowe, Uncle Tom's Cabin (Chicago, 1914 [1852]), 45.

${ }^{34}$ Stowe, 46. Stowe's use of 'sympathy' is roughly equivalent to our use of 'empathy.' See note 4.
} 
the agency of enslaved and free Black people. By reading these narratives, whites were meant to cultivate an appreciation of enslaved and free Black Americans' standing as free, equal, but mutually dependent moral and political actors. In other words, these narratives addressed the epistemic and affective gap that was both instrumentally and constitutively part of the problem antislavery aimed to address by cultivating empathy with Black people in the US.

Crucially, abolitionists who sought to address this epistemic and affective gap by means of empathy-cultivating narrative typically believed that their narratives were effective only if they were 'authentic.' Stowe urges throughout the preface to Uncle Tom's Cabin that the details of her narrative, in spite of its being a work of fiction, are 'authentic,' and she eventually defends this claim in a second book, The Key to Uncle Tom's Cabin. More generally, as Nolan Bennett observes, the traditional function of former slaves' narratives was to "reorient white readers' moral compasses" by providing "empirical proof" concerning the conditions of slavery. ${ }^{35}$ In other words, these narratives sought to persuade white audiences to judge that slavery was wrong and urgent action was needed by presenting the experiences of slaves for these audiences: a narrative was understood to articulate a perspective on the world for the reader to inhabit. As Bennett observes, because former slaves' narratives were treated as "empirical proof," it was urgent—in the eyes of white abolitionists - to authenticate them as accurate testimony. Robert Stepto observes that this demand crystalizes into a genre he labels "authenticating narrative," in which white abolitionists would pen prefaces affirming the accuracy of the narrative, and in which the narrative itself would focus on providing verifiable details. ${ }^{36}$

It is plausible to think that there is a productive connection between the authenticity of a narrative in this sense and its efficacy in cultivating empathy: if the aim of a narrative is to bring

\footnotetext{
${ }^{35}$ Nolan Bennett, "To Narrate and Denounce: Frederick Douglass and the Politics of Personal Narrative," Political Theory 44, no. 2 (2016): 245.

${ }^{36}$ Robert B. Stepto, From behind the Veil : A Study of Afro-American Narrative (Urbana: University of Illinois Press, 1991).
} 
reader to appreciate the perspective of a person or group, the narrative ought to accurately depict the person or group's perspective. But, as I will argue in the next section, this commitment to 'authenticity' in fact grounded an ineliminably paternalistic attitude in white readers, which frequently rendered the political judgments they'd make on the basis these narratives unresponsive to the agency of enslaved and free Black people.

\section{Critique of Empathy}

This demand for authentication — so that white audiences could be sure they were empathizing with a 'genuine' perspective - ends up, in many important cases, re-inscribing the very sorts of oppressive, racist hierarchies that the narratives are meant to combat. Whites' appeals to authenticity in antislavery narratives are persistently bound up with paternalism and unresponsiveness to the agency of Black political actors. Ultimately, I argue in this section, this is because the aspiration to empathize with an 'authentic' perspective invokes a political epistemology on which we reduce one another to bodies of preferences and facts.

Responsiveness to agency is incompatible with a picture on which the known and being known of emancipated political life consists in learning more facts about one another; this incompatibility emerges starkly in the political judgments of white abolitionists grounded in empathetic appreciation of the situation of enslaved Black people.

In April 1863, Harriet Beecher Stowe publishes an article in The Atlantic about a series of exchanges with Sojourner Truth at while Truth was lodging at Stowe's house. ${ }^{37}$ The article recounts compelling episodes of Truth's antislavery resistance, such has her struggle to recover her son from Alabama, and captures Truth's prophetic fire. ${ }^{38}$

But the article also caricatures Truth. Stowe characterizes Truth's singing voice as having "the strong barbaric accent of the native African." She describes Truth as embodying "the fervor

\footnotetext{
${ }^{37}$ Harriet Beecher Stowe, "Sojourner Truth, The Libyan Sibyl," The Atlantic, April 9, 1863, https://www.theatlantic.com/magazine/archive/1863/04/sojourner-truth-the-libyan-sibyl/308775/.

${ }^{38}$ Cornel West, Cornel West on Black Prophetic Fire (Boston: Beacon Press, 2014).
} 
of Ethiopia, wild, savage, hunted... but burning after God in her tropic heart." And most strikingly, Stowe depicts Truth as speaking with a stereotypical southern accent (e.g., "Well, honey, de Lord bless ye! I jes' thought I'd like to come an' have a look at ye. You's heerd o' me, I reckon?"), whereas in fact Truth was born into slavery in New York and grew up speaking Dutch.

Stowe, it seems, invokes these racist tropes in order to authenticate the narrative for a white audience - to make Truth's words 'ring true' to them. But, in addition to the inconsistency in 'authenticating' Truth by appeal to falsehoods (concerning her diction), Stowe's depiction of Truth undercuts her agency. Truth is depicted as an agent determined by her white audience's essentializing and racist assumptions about enslaved Black people. Truth, in Stowe's article, is reduced to a persona composed of racist tropes for white readers to inhabit. Moreover, Truth's agency is undercut because Stowe, as the author of the article, sets the terms of the narrative. While Stowe presents the article as about Truth and her situated perspective on the world, the perspective a white audience is invited to inhabit is ultimately Stowe's, as Truth's host and interlocutor.

At this stage, it would be natural to point out that Stowe's article does not by itself serve as an obvious indictment of empathy's role in emancipatory politics. Stowe neither puts her audience in a position to empathize with Truth's actual perspective nor appreciate Truth's agency. One could maintain, in this case, that it is precisely the inauthenticity of Stowe's portrayal of Truth that undermines its efficacy in bridging epistemic and affective gaps for white readers.

There are two ways in which Stowe's article fails to present Truth's perspective authentically. First, Stowe fails to accurately represent Truth, as when she represents Truth with a stereotypical southern accent. Second, by depicting Truth through a series of essentializing and racist assumptions about enslaved Black people, Stowe fails to present her readers with Truth's own 
voice — Truth does not (directly or indirectly) articulate her own perspective for her audience. Thus, there are two ways in which 'authentic' empathizing (i.e., empathizing with an 'authentic' perspective) might help a privileged audience to address epistemic and affective deficits toward marginalized persons or groups. Authentic empathizing might depend on accurately representing the perspective an audience is to empathize with, or it might depend on an agent articulating her own perspective.

But when we look to the role of narrative in antebellum abolitionist politics, we find that neither sense of authenticity suffices to address whites' epistemic and affective deficits towards enslaved and free Black people, because both senses of 'authentic' empathizing ground paternalistic judgments by white abolitionists. This is because, I claim, the very idea of empathizing with an authentic perspective expresses a picture of political agency as reducible to interests and capacities, where the task of politics is to maximize the satisfaction of interests by optimizing the exercise of political actors' capacities. Where political actors' capacities are uneven, or perceived to be uneven, those privileged with (apparently) greater capacities will tend to exercise political judgment in ways unresponsive to the agency of those with (apparently) lesser capacities.

Stowe's Uncle Tom's Cabin is infamous for the stereotypic depictions of enslaved Black people that it invokes (and indeed plays a substantial role in producing). But the novel does also present at least some rich and complex perspectives for readers to inhabit. For instance, Stowe depicts George Harris's animus towards his owner and slavery generally as grounded in merit: 'My master! and who made him my master? That's what I think of-- what right has he to me? I'm a man as much as he is. I'm a better man than he is. I know more about business than he does; I am a better manager than he is; I can read better than he can; I can write a better hand-- and I've learned it all myself, and no thanks to him-- I've 
learned it in spite of him; and now what right has he to make a dray-horse of me? to take me from things I can do, and do better than he can, and put me to work that any horse can do? He tries to do it; he says he'll bring me down and humble me, and he puts me to just the hardest, meanest, and dirtiest work, on purpose! ${ }^{39}$

Harris, at the outset of the novel, is moved to resist his condition as a slave because he sees it as incompatible with an understanding of social relations as justified by merit and capacity. Harris's normative orientation toward the world helps the reader to inhabit his perspective, because it enables the reader to explain his actions and imagine alternative ways he plausibly might act. Harris's normative orientation guides the reader's imaginative projection into his perspective. But although Stowe, at least at times, offers her readers normatively rich, and thus plausibly accurate, perspectives to inhabit, she herself characterizes the empathetic understanding generated in paternalistic terms. Through artistic projects like hers, Stowe writes in the preface to Uncle Tom's Cabin: "[T]he heart of the dominant race, who have been her conquerors, her hard masters, has at length been turned toward [the African race] in mercy; and it has been seen how far nobler it is in nations to protect the feeble than to oppress them." ${ }^{40}$ Empathetic understanding, Stowe claims, turns the hearts of white readers toward a commitment to protect, rather than oppress, enslaved and free Black people in the US. We see that this commitment to protect amounts to paternalistic unresponsiveness to the agency of enslaved and free Black people in Stowe's own political judgment in the period. In a May 1853 letter to Douglass, Martin Delany criticizes Stowe's support for white-led colonization projects in the novel, as well as her plan for an industrial college for Black Americans headed exclusively by white instructors. On the former, Delany maintains that such colonization projects aim to ensure that Black people who emigrate remain "subservient to... white men's power." On the latter,

\footnotetext{
${ }^{39}$ Stowe, Uncle Tom's Cabin, 69.

${ }^{40}$ Stowe, 46.
} 
Delany observes an educational institution which embodies such racial hierarchies "creates the impression that colored persons are incapable of teaching, and only suited to subordinate positions." Ultimately, Delany maintains that Stowe's judgment in these matters fails to abide by the principle that "no enterprise, institution, or anything else, should be commenced for us, or our general benefit, without first consulting us." By failing to abide by this principle, Stowe, in her political judgment "is treating us as slaves, and presupposing us all to be ignorant." empathetic understanding that Stowe achieves, in her ability to articulate normatively rich perspectives for enslaved Black people, does not render her own political judgment responsible to the agency of Black political actors, much less that of her readers.

Indeed, Stowe's empathetic understanding seems to exacerbate her paternalistic judgment. It is important to note that in his letter, Delany oversimplifies the situation concerning Stowe's planned industrial college: Stowe plans this industrial college in part based on advice from Douglass in a March 1853 letter. But Stowe engages with Douglass as an expert on what is in the best interest of Black Americans. ${ }^{42}$ This is evidenced in Douglass's own concession that "I leave the organization and administration [of the college] to the superior wisdom of yourself and the friends who second your noble efforts" because "[i]t is the peculiarity of your favored race that they can always do what they think necessary to be done. I can safely trust all details to yourself, and the wise and good people whom you represent in the interest you take in my oppressed fellow countrymen.." ${ }^{\not 3}$ Douglass's advice functions as testimony which informs Stowe's judgment about how to act in the best interests of Black Americans. While the support she provides is likely valuable to the cause, as Douglass himself underscores in his response to Delany's letter, its value is not grounded in robust responsiveness to the agency of enslaved and

\footnotetext{
${ }^{41}$ Martin Delany, “Mrs. Stowe's Position," Frederick Douglass' Paper, May 6, 1853. Emphasis his

${ }^{42}$ Frederick Douglass, "To Harriet Beecher Stowe, March 8, 1853," in Frederick Douglass: Selected Speeches and Writings, ed. Philip Foner and Yuval Taylor (Chicago: Lawrence Hill Books, 1999), 213-19.

${ }^{43}$ Douglass, 217.
} 
free Black people in the US. Stowe judges and acts to supplement perceived incapacities of Black Americans for the sake of what she takes to be their best interest. The fact that Stowe's judgment is informed by Douglass qua expert on the condition of Black Americans simply reveals that Stowe's orientation is toward the perceived interest of marginalized political actors, rather than toward their agency: the accuracy of Stowe's empathetic understanding does not render her political judgment responsible.

If accuracy in empathetic understanding does not render political judgment responsible, a proponent of authentic empathy might instead hold that empathetic understanding renders political judgment responsible when the perspective is articulated by the right source. If I come to understand your perspective through your own articulation of it, one might think, I am wellpositioned to appreciate your standing as a free, equal, but mutually dependent agent, and in particular to exercise political judgment in ways responsive to your agency. But Douglass's account of his work with the Garrisonians in My Bondage and My Freedom shows that his own articulation of his perspective for white audiences, for the sake of empathetic understanding, undercut appreciation of his agency.

In the early 1840 s, the Garrisonians deploy Douglass on the anti-slavery talking circuitlectures for the public organized by abolitionists seeking to persuade the public to endorse antislavery. Douglass, at these events, is meant to provide a narrative of his experiences as a slave as part of the Garrisonians' anti-slavery argument. But Douglass recounts that his role among the Garrisonians was severely circumscribed. Douglass is "generally introduced as a "chattel"- a "thing" - a piece of southern "property" - the chairman assuring the audience that it could speak." ${ }^{44}$ This might again appear to be a problem concerning a lack of empathy; indeed, a radical lack of empathy, as Douglass is introduced as a 'thing' lacking a perspective of his own. But Douglass observes that his telling of his own story was itself bound up with his

\footnotetext{
${ }^{44}$ Douglass, My Bondage and My Freedom, 220.
} 
objectification before these audiences. Douglass notes that he was instructed by one of the Garrisonians to "Give us the facts... we will take care of the philosophy." ${ }^{45}$ With this instruction, the Garrisonians rendered Douglass a mere vehicle for providing testimony to their audience (at least to the extent that Douglass cooperated with the Garrisonians). The white Garrisonians position themselves to draw on Douglass's testimony in order to make arguments and offer political judgments for their audience to endorse. The division of political labor the Garrisonians demarcate between Black and white abolitionists - between supplying the narrative and making the argument - renders Douglass a mere body of testimony, a perspective for white audiences to inhabit and make political judgments on the basis of. It is precisely because Douglass's role is circumscribed to a presentation of his perspective for white audiences to take up that he is reduced by the Garrisonians to a mere body of testimony, rather than a free and equal political actor. The objectification of Douglass as a body of testimony for white audiences to inhabit suggests that the political judgments white abolitionists make on the basis of empathic connections will not be adequately responsive to the political agency of enslaved and free Black people.

Authentic empathy, understood either in terms of empathizing with an accurate perspective or in terms of empathizing with the perspective articulated by an agent herself, does not render political judgment responsible. The inefficacy of empathy in making us responsive to the agency of others is grounded in a disconnect between the knowing and being known of empathetic understanding, and what it is to know others and be known as free, equal, but mutually dependent agents. When we inhabit someone else's perspective, we are acquainted with the way the world appears to her. In particular, we are acquainted with her best interests: what she values and what is valuable for her. Thus a reader of Uncle Tom's Cabin comes to appreciate George Harris's value of merit-based recognition; a member of Douglass's audience come to appreciate

\footnotetext{
${ }^{45}$ Douglass, 220.
} 
(for instance) the way in which he values freedom as non-domination (freedom not just from the mere incidents of slavery, but slavery itself). But to appreciate what another person values is not to appreciate her as an agent who acts in pursuit of what she values.

This disconnect manifests in political judgment in the following way. If I appreciate what is in someone's best interests, I can, with some degree of reliability, judge what is good for her in particular circumstances. At the same time, people are sometimes not in the best position to judge what is in their own best interests - sometimes we make mistakes in judging what is good for ourselves. Moreover, when someone is subject to oppression, she is sometimes constrainedboth epistemically and practically — in judging and pursuing what is in her own best interest.

Privileged political actors who empathize with oppressed political actors think — perhaps even correctly — that they can judge what is in the latter's best interests. Moreover, they mayperhaps even justifiably — think that oppressed political actors are not reliable judges of their own best interests. If all that one seeks in political judgment is to judge and act in someone's best interests - which is all that empathy alone equips us to judge on the basis of - privileged political actors will think that they ought to exercise political judgment on behalf of oppressed political actors, because they are better positioned to exercise such judgment.

But a judgment made on someone else's behalf in this way effaces, rather than responds to, her agency. Such judgments are not responsible to marginalized political actors. To put the point provocatively: when I make a judgment that affects you because I have, and you lack, an appreciation of your own best interests, I express contempt for your political agency. Such judgment expresses a desire not merely to influence, but to override the political agency of others. It is a desire to exercise one's own political judgment on a frictionless plane.

This critique does not demonstrate that those engaged in emancipatory politics always ought to prioritize responsibility over other values (e.g., maximization of interests) in political 
judgment. ${ }^{46}$ Instead, this critique demonstrates that, contrary to the understanding of many antebellum white abolitionists, cultivating empathy is not a reliable means for making the political judgment of privileged political actors responsible to the agency of marginalized political actors. This is because the aspiration to empathize with an authentic perspective invokes a picture of political judgment as a matter of maximizing the satisfaction of interests through the optimal utilization of capacities. On this picture, we cannot make intelligible the idea that it is intrinsically valuable for me to exercise my agency (in concert with others) in pursuit of my interests. The critique itself does not justify this value, but it does shows that if we want to make room for it, we need a different picture of political judgment, and thus a different story about how we bridge epistemic and affective gaps among members of a polity. ${ }^{47}$

\section{Humility and Acknowledgment}

In the context of emancipatory politics, the political judgment of privileged political actors can fail to be responsible by failing to acknowledge the agency of persons and groups subject to oppression. Because these failures of political judgment stem from an epistemic and affective gap between privileged and marginalized political actors, it is intuitive to think that we make privileged actors' political judgments responsible to marginalized actors by bridging this gap. But we've seen that efforts at bridging this gap through the cultivation of empathy are liable to be counterproductive. The irony of this critique is that learning more about other persons and groups can inhibit our acknowledgment of their agency — at least when it is not tempered by an appreciation of one's own situatedness.

\footnotetext{
${ }^{46}$ This is implied by Douglass's response to Delany's May 1853 letter concerning Stowe. Douglass urges that Stowe's efforts contribute instrumentally to the antislavery cause, and ought to be valued as such: "Whoever will bring a straw's weight of influence to break the chains of our brother bondmen, or whisper one word of encouragement and sympathy to our proscribed race in the North, shall be welcomed by us to that philanthropic field of labor." Frederick Douglass, "The Letter of M.R. Delany," Frederick Douglass' Paper, May 6, 1853. ${ }^{47}$ That said, I think that there is a compelling case that responsiveness to agency is an integral value in emancipatory politics, especially when one understands the task of emancipatory politics as reforging political communities more inclusively through the exercise of political agency in ways that forges social bonds of love, trust, loyalty, solidarity, and non-paternalism. I leave this argument for future work.
} 
Rectifying the irresponsibility of privileged political actors' judgment in the context of emancipatory politics requires, I claim, that we cash out the role of humility in acknowledging one another's agency. Appreciating others as free, equal, but mutually dependent agents is something that we achieve through an appreciation of the limits of our own agency and our own situatedness.

Cavell, in "The Avoidance of Love," observes that acknowledgment of another is, at the same time, acknowledgement of one's own particular and limited position in the world. Acknowledgement "requires self-revelation" which confirms one's "separateness... from others. ${ }^{, 48}$ This self-revelation is produced by a confrontation with another person, through which we appreciate what she thinks, feels, and does as her thoughts, feelings and actions - as things we can relate to, but cannot possess ourselves. In appreciating another's thoughts, feelings, and actions as her, we come to acknowledge her as a free and equal agent. But, crucially, this acknowledgment of another cannot be achieved except through an inward turn- self-revelation of one's own situatedness and limits - prompted by a confrontation with her agency.

It might seem puzzling that acknowledging another as a fellow agent involves a turn towards oneself. But this is in fact an ordinary feature of social life. Iris Murdoch illustrates this point in chapter one of The Sovereignty of Good in her example of a mother who views her daughter-inlaw contemptuously (although she does not express this view in her behavior). Murdoch describes a shift in the mother's perspective on her daughter-in-law, in which she comes to see her no longer as "pert and familiar, insufficiently ceremonious, brusque" and so on, but now as "spontaneous... gay... delightfully youthful." What brings on this change in the mother's perspective is that the mother comes to recognize ("tells herself"): "I am old-fashioned and conventional. I may be prejudiced and narrow-minded. I may be snobbish. I am certainly jealous.

\footnotetext{
${ }^{48}$ Stanley Cavell, "The Avoidance of Love: A Reading of King Lear," in Must We Mean What We Say (Cambridge: Cambridge University Press, 1969), 338.
} 
Let me look again. ${ }^{\star 49}$ Murdoch describes how the mother directs "careful and just attention to an object which confronts her." ${ }^{50}$ The mother's change in perspective concerning her daughter involves a confrontation through which the mother makes an inward turn, through which she comes to appreciated her situatedness and limits (in this case expressed largely by a recognition of faults and biases, but it need not take this shape in all cases). In other words, the mother comes to see her daughter-in-law more clearly for who she is by taking on an attitude of humility. ${ }^{51}$

Some antebellum Black abolitionists, I claim, sought to catalyze this inward turn through humility-inducing confrontations with white readers in their narratives. Frederick Douglass engages in such confrontations with white readers in pivotal moments in his second autobiography My Bondage and My Freedom.

In perhaps the starkest example in the text, Douglass does not describe his successful escape in detail. This is in part, as Douglass explicitly states, so that he does not give away means that other slaves can use to escape themselves: "Such is my detestation of slavery, that I would keep the merciless slaveholder profoundly ignorant of the means of flight adopted by the slave." ${ }^{52}$ But Douglass also urges that anti-slavery readers are often themselves responsible to the anti-slavery cause to the extent that they remain in targeted ignorance concerning the details of successful efforts at escape from slavery: "By stringing together a train of events and circumstances, even if I were not very explicit, the means of escape might be ascertained, and, possibly, those means be rendered, thereafter, no longer available to the liberty-seeking children of bondage I have left behind me. No antislavery man can wish me to do anything favoring such results.. ${ }^{53}$ The tendency of abolitionists to publish such accounts, Douglass claims, constitutes unresponsiveness

\footnotetext{
${ }^{49}$ Iris Murdoch, The Sovereignty of Good (Florence, KY: Routledge, 2001), 17-18.

${ }^{50}$ Murdoch, 18.

${ }^{51}$ Importantly, for Murdoch, this change in perspective is not a reinterpretation of indeterminate/brute behavior. Rather it is something like a coming to appreciate her daughter-in-law for 'who she really is' (as we could imagine the mother herself putting it).

${ }^{52}$ Douglass, My Bondage and My Freedom, 197.

${ }^{53}$ Douglass, 195.
} 
to the interests and agency of enslaved people: "In publishing such accounts, the anti-slavery man addresses the slaveholder, not the slave; he stimulates the former to greater watchfulness, and adds to his facilities for capturing his slave. We owe something to the slaves, south of Mason and Dixon's line, as well as to those north of it; and, in discharging the duty of aiding the latter, on their way to freedom, we should be careful to do nothing which would be likely to hinder the former, in making their escape from slavery." ${ }^{, 54}$ In deciding to publish accounts of successful escape attempts, the judgment of abolitionists is irresponsible to enslaved people — responsible political judgment in these circumstances requires restraining the desire to disseminate and consume riveting stories of escape. But appreciation of what responsible political judgment demands in these circumstances involves humble recognition of one's situatedness - that, for most white anti-slavery readers, their ignorance in particular matters is a contribution to the cause to which they are committed. Douglass's explicit refusal to provide the details of his successful escape induces his readers to an appreciation of the interests and agency of enslaved people through an inward turn concerning his readers' position in the movement and its primary aims - that is, by inducing humility in his readers about the importance of their curiosity and understanding concerning particular matters in the context of the wider aims of their movement.

But Douglass does not only cast the importance of humility in straightforwardly strategic terms. In his concluding remarks on his fight with the 'slavebreaker' Covey, Douglass distances his (typical) reader, stating: "He only can understand the effect of this combat on my spirit, who has himself incurred something, hazarded something, in repelling the unjust and cruel aggressions of a tyrant." 55 Whereas Douglass's vivid depiction of the fight invites the reader to take up his perspective, Douglass asserts at the moment the reader would have taken herself to have achieved this empathetic connection that she is not in a position to do so. In the following

\footnotetext{
${ }^{54}$ Douglass, 196-97. Emphasis his.

${ }^{55}$ Douglass, 151.
} 
lines he goes on to strengthen the claim: one must hazard their life and no longer be "afraid to die" in order to fully appreciate Douglass's situation. ${ }^{56}$ Even in one of the episodes that most intuitively invites empathetic identification with Douglass, in Bondage Douglass reminds his readers of their limits (unless, of course, they themselves have risked their lives in struggle against tyranny). ${ }^{57}$ The limit Douglass confronts his readers with prompts an inward turn in which they recognize Douglass's standing as a separate political actor through the fact that he has hazarded his own life in struggle against tyranny and oppression. ${ }^{58}$

These confrontations, in which Douglass distances himself from his (typical) reader in a way that effects an inward turn and a humble appreciation of their situatedness with respect to Douglass himself and the antislavery movement more generally, contribute to one of his central narrative aims. Andrews observes that throughout Douglass's antebellum narrative writings, he seeks to overcome white readers' disinterested perspective, on which their judgment about slavery is informed by a set of un-perspectival facts: "Douglass did not want to indulge his reader in a servile way [i.e. supplying them with a mere set of facts]; he wanted his reader to learn something about his or her responsibility to the text," and, through this, to learn something about the nature of his or her responsibility to enslave and free Black Americans as free and equal, but mutually dependent, political actors. ${ }^{59}$ In the Narrative, Douglass thinks that this disinterest can be overcome through imaginative self-projection and empathy ${ }^{60}$

But in Bondage, I claim, Douglass thinks that the right kind of interested perspective (i.e., one that renders white people's political judgment responsible to enslaved and free Black

\footnotetext{
${ }^{56}$ Douglass, 152.

${ }^{57}$ We should also be careful about overstating the strength of this condition. Risking one's life in political struggle need not consist in an intention to sacrifice oneself, nor in even in a plan that one cognizes as involving substantial risk. Sometimes we find our lives at risk in what we think are mundane political actions (e.g. the peaceful demonstration at which the police fly off the handle). But appreciation of this fact requires an inward turn that is indicative of humility on the model we've sketched in this section.

${ }^{58}$ So, even if a reader does find herself similarly situated, she nevertheless comes to appreciate Douglass's hazarding of his life as his own exercise of political agency.

${ }^{59}$ Andrews, To Tell a Free Story, 137.

${ }^{60}$ Andrews, 135-37.
} 
Americans) must be shaped by humility. The right kind of interested perspective, on this picture, is mediated by a humble appreciation of the limits of one's agency and position with respect to others. By inducing humility in his white readers, Douglass orients them toward the political agency of free and enslaved Black people resisting slavery.

But whereas the role of humility in the shift toward the right kind of interested perspective is implicit in Douglass's post-Garrisonian thought, Harriet Jacobs explicitly theorizes it in her Incidents in the Life of a Slave Girl. The epigraph to the narrative, which Jacobs attributes to "a woman of North Carolina," identifies an epistemic and affective gap as one barrier to whites' involvement in the antislavery movement: "Northerners know nothing at all about Slavery. They think it is perpetual bondage only. They have no conception of the depth of degradation involved in that word, SLAVERY; if they had, they would never cease their efforts until so horrible a system was overthrown." The aim of Jacobs' narrative is to address this epistemic and affective gap, especially attuning white women to the condition of enslaved Black women:

I do earnestly desire to arouse the women of the North to a realizing sense of the condition of two million of women at the South, still in bondage, suffering what I suffered, and most of them far worse. I want to add my testimony to that of abler pens to convince the people of the Free States what Slavery really is. Only by experience can any one realize how deep, and dark, and foul is that pit of abominations. ${ }^{61}$

Jacobs intends for her narrative to cultivate understanding and compassion in her readers, which will spark concrete support for the antislavery cause. But as the final line itself signals, there is an intrinsic challenge to this project: the epistemic and affective gap that Jacobs intends to address is itself a product of white Northern women's lack of experience of slavery's conditions. Jacobs' narrative, and former slaves' narratives more generally in this period, are meant to rectify white women's lack of experience and thereby spur them to antislavery action.

\footnotetext{
${ }^{61}$ Harriet A. Jacobs and Lydia Maria Francis Child, Incidents in the Life of a Slave Girl Written by Herself, 1860, 6.
} 
It is intuitive to think that narrative serves this role by functioning as a substitute for experience. Jacobs invites this reading by casting her narrative as testimony through which white readers gain greater understanding and affective appreciation for the condition of enslaved Black women. Jacobs' story articulates a perspective for readers to inhabit through imaginative projection, and thereby empathetically stands in for an experience of the conditions of slavery

But in Incidents, Jacobs at times despairs at the possibility of forging an antislavery movement through empathetic understanding. While describing the role of sexual violence in the tyranny and oppression to which slaves are subjected, Jacobs laments that:

The degradation, the wrongs, the vices, that grow out of slavery, are more than I can describe. They are greater than you would willingly believe. Surely, if you credited one half the truths that are told you concerning the helpless millions suffering in this cruel bondage, you at the north would not help to tighten the yoke. You surely would refuse to do for the master, on your own soil, the mean and cruel work which trained bloodhounds and the lowest class of whites do for him at the south. ${ }^{62}$

While Jacobs begins by noting the limits of her capacities in capturing the wrongs and horrors of slavery, she quickly observes that even if she were able to adequately articulate these wrongs and horrors (indeed, as any reader of Incidents might judge), white northerners will not take Jacobs at her word, for the details of slavery are 'greater than you would willingly believe.' In attempting to bridge this epistemic and affective gap for white northerners concerning the conditions of slavery through narrative, Jacobs runs up against testimonial injustice- her readers will not come to inhabit her experience because they do not believe her narrative. ${ }^{63}$

Jacobs develops this problem in describing the funeral of her Aunt Nancy:

Northern travellers, passing though the place, might have described this tribute of

\footnotetext{
${ }^{62}$ Jacobs and Child, 45.

${ }^{63}$ Miranda Fricker, Epistemic Injustice: Power and the Ethics of Knowing (New York: Oxford University Press, 2007).
} 
respect to the humble dead as a beautiful feature in the 'patriarchal institution;' a touching proof of the attachment between slaveholders and their servants; and tenderhearted Mrs. Flint would have confirmed this impression, with handkerchief at her eyes. We could have told them a different story. We could have given them a chapter of wrongs and sufferings, that would have touched their hearts, if they had any hearts to feel for the colored people. We could have told them how the poor old slave-mother had toiled, year after year, to earn eight hundred dollars to buy her son Phillip's right to his own earnings; and how that same Phillip paid the expenses of the funeral, which they regarded as doing so much credit to the master. We could also have told them of a poor, blighted young creature, shut up in a living grave for years, to avoid the tortures that would be inflicted on her, if she ventured to come out and look on the face of her departed friend. ${ }^{64}$

Jacobs imagines white northerners misapprehending the character and context of Aunt Nancy's funeral because they would fail to consult, or consider the perspective of, enslaved people in the community. Instead, they would allow the outward grandeur of the funeral to simply confirm their understanding of slavery as a 'patriarchal institution' which is ultimately to the benefit of the enslaved. While any enslaved person in the community could readily dispel such misconceptions, Jacobs observes that they simply would not be consulted by northern travelersthey would be subjected to 'testimonial quieting. ${ }^{65}$

In passages like these, Jacobs despairs at the possibility of moving white northerners to action against slavery, because narratives like hers are ineffective at bridging the epistemic and affective gap that leaves whites apathy about the condition of enslaved Black people. She finds that enslaved Black people are not taken as sources of testimony by white northerners, and that

\footnotetext{
${ }^{64}$ Jacobs and Child, Incidents in the Life of a Slave Girl Written by Herself, 222-23.

${ }^{65}$ Kristie Dotson, “Tracking Epistemic Violence, Tracking Practices of Silencing," Hypatia 26, no. 2 (2011): 236-57.
} 
even when the opportunity to supply testimony arises, their testimony is not afforded adequate credence. In light of these passages, it is tempting to read Jacobs' remark in the preface that "only experience" can capture the wrongs and horror of slavery to mean that it is not otherwise possible to appreciate the conditions of slavery, because mechanisms of epistemic oppression decisively compromise the privileged's capacity to inhabit the perspective of the marginalized. Narrative cannot serve as an adequate substitute for experience.

But if this were Jacobs' position, the existence of Incidents itself would be puzzling. The fact that Jacobs crafted this narrative and addressed it to white readers implies that she thinks there is some role for narrative in addressing the epistemic and affective gap between white and Blacks in the antislavery movement. The interpretive key, I think, is to note that Jacobs directs this despair at the possibility of white northerners inhabiting the perspective of enslaved Black women to her white readers. Her expressions of despair are a way in which Jacobs refuses to engage with her audience exclusively on the terrain of testimony and narrative.

Jacobs, I claim, understands such refusals at integral to bridging the epistemic and affective gap. These refusals are expressions of Jacobs' authorial agency that induce humility in her privileged readers. For instance, in recounting the relationship she started with the attorney Mr. Sands in order to deflect the advances of her owner Dr. Flint, Jacobs states:

Pity me, and pardon me, O virtuous reader! You never knew what it is to be a slave; to be entirely unprotected by law or custom; to have the laws reduce you to the condition of a chattel, entirely subject to the will of another. You never exhausted your ingenuity in avoiding the snares, and eluding the power of a hated tyrant, you never shuddered at the sound of his footsteps, and trembled within the hearing of his voice. I know I did wrong. No one can feel it more sensibly than I do. The painful and humiliating memory will haunt me to my dying day. Still, in looking back, calmly, on the events of my life, I 
feel that the slave woman ought not to be judged by the same standards as others. ${ }^{66}$ At first pass, in this passage Jacobs seems to beseech herself in a subservient manner to her reader. She asks for pity and pardon, expresses recognition that she acted wrongly, and suggests that her actions might be judged by a different standard than in other circumstances. It is true that Jacobs at times invites her reader to take on a paternalistic attitude (or perhaps simply acknowledges her reader's disposition to such an attitude) ${ }^{67}$ But there is another important strand in this passage. Jacobs confronts her audience with their inability to fully appreciate her position as an enslaved woman facing persistent harassment from her owner. In light of this limit, Jacobs implies that her reader is in no position to judge her actions in this circumstance: Jacobs emphatically consults her own authority as author of her own narrative, not the standards or judgment of her readers. In this passage, Jacobs subverts her audience's paternalistic disposition to render judgment; Jacobs' claim that "No one can feel it more sensibly than I do" is not, ultimately, the expression of an internalization of her reader's moral standards, but rather an expression of her autonomous moral agency. In other words, Jacobs recognizes her reader's disposition to render judgment on her actions, but ultimately refuses to acknowledge their judgment as applicable or appropriate, because they cannot appreciate what it is like to confront such choices as a slave. Jacobs' critique of her reader's disposition is not that they ought to apply a different normative standard in judging her actions, but that her actions are not theirs to judge.

Jacobs holds that her white readers are not in a position to render judgment on her actions because they do not fully understand her situation as an enslaved Black woman. But for Jacobs, this is not a problem to be solved by suppling narrative details. Instead, it is a point that she confronts her readers with by withholding such detail at pivotal moments, in order to bring her readers to acknowledge their limits and situatedness. Jacobs' narrative aim is not to enable her

\footnotetext{
${ }^{66}$ Jacobs and Child, Incidents in the Life of a Slave Girl Written by Herself, 86.

${ }^{67}$ Jacobs and Child, 45, 113.
} 
reader to take up her perspective so as to make judgments informed by it, but rather to appreciate her perspective as her own, and Jacobs herself as a fellow agent to whom her reader ought to be responsible in exercising political judgment.

Jacobs' explicit refusals to supply her reader with details thus induces humility. This humility is, in the first place, an inward turn through which her readers appreciate their situatedness by confronting the limits of their understanding of other persons' situations. This appreciation manifests, for Jacobs, in her readers' withholding of judgment concerning the ways in which Jacobs herself navigated her situation in slavery.

But the humility that Jacobs aims to induce is not quietistic; it does not prescribe that white Northerners ought to wholly refrain from judgment or action. Jacobs, after all, is seeking to spur her readers to action against slavery and white supremacy. Jacobs, moreover, understands white Northerners' inaction against slavery and white supremacy as largely the product of an epistemic and affective gap in which white Northerners fail to appreciate the wrongs and horrors to which enslaved Black people are subjected. Humility, on Jacobs' picture, is integral to the orientation white Northerners must adopt in order to exercise political judgment in ways that are responsible to enslaved Black people. Exercising political judgment responsibly is not simply a matter of discerning what the correct decision is in each case. Rather, exercising political judgment responsibly is largely a matter of understanding where one's judgment is called for, and in what ways. We appreciate the agency of other persons with whom we are engaged in shared projectsnot simply by discerning what is best from their perspective, but by acting in ways that the capacity for political judgment that they themselves possess.

The fact that Jacobs offers a rich narrative of her experience in slavery does also imply that empathy plays an important role in emancipatory politics: inhabiting the perspective of another can inform our judgment in important ways, and motivate us to action. But this understanding is 
productive for emancipatory aims only when it is shaped by a humble orientation towards one's relation to other persons as free, equal, but mutually dependent political agents. Where empathy is tempered by humility, we make our political judgment responsible to one another by attuning ourselves to our limits and situatedness with respect to one another.

The shift in orientation that Douglass and Jacobs' confrontations with the reader effect is, importantly, an epistemic shift. In tempering empathetic understanding with humble appreciation of other persons' agency, we move from a picture on which the knowing and being known of emancipatory politics is grounded fundamentally in the acquisition of facts about one another to a picture on such mutual understanding is fundamentally grounded in acknowledgment of one another as free and equal but mutually dependent actors in political life.

\subsection{Acknowledgment and Emancipatory Social Bonds}

By way of conclusion, let me preempt one possible misinterpretation of my thesis. My claim in this chapter is not that we ought only to exercise humility, and never empathy, in emancipatory politics. Empathy informs political judgment because it helps us to understand what fellow members of our community value. Humility alone, moreover, leads to untempered subservience to others, as Douglass himself observes: "I have met many religious colored people, at the south, who are under the delusion that God requires them to submit to slavery, and to wear their chains with meekness and humility. ${ }^{98}$ In order to exercise political judgment well, we must both appreciate other persons as agents who act in pursuit of what they value, and understand what is valued - both by ourselves and other members of our community. Humility shapes our political judgment so that it is responsible to others as fellow agents; empathy informs our political judgment so that it is responsive to what other members of our community value.

But the relationship between humility and empathy is not merely additive; it is not that humility provides one ingredient for good political judgment, and empathy a wholly independent

${ }^{68}$ Douglass, My Bondage and My Freedom, 101. 
one. Rather, in adopting a humble orientation towards others as free, equal, but mutually dependent agents, we transform our understanding of how persons relate to their interests and values as political agents. Absent humility, we are tempted to think that there is a straightforward fact of the matter about what a person values (although this fact may change over time). Absent humility, the challenge appears to be to discover what is in a person's best interests, either by relying upon her own introspection or other external means. But casting the challenge in this way offers only a very weak connection between what a person values and her distinctive relationship to her values as her own: at best, it just so happens that each of us is typically best situated to know what she herself values. It is precisely this weak connection, on which what one values, or what is in one's interest, is simply a fact of the matter in need of discovery, that leads privileged political actors to exercise judgment paternalistically on behalf of marginalized political actors. Informed by empathy, privileged political actors think they are better situated to understand what is in the best interest of marginalized political actors- privileged political actors operating on the basis of empathy simply see this as an atypical case.

In adopting an attitude of humility towards others as free, equal, but mutually dependent agents, we are equipped to recognize a thicker connection between a person and her values, on which a person's exercise of her own agency plays an integral role in shaping what she values (what is in her own best interest). This connection is manifest in Douglass's own plantation politics. While enslaved on the Freeland plantation, Douglass organizes his first attempt at escape from slavery. In this effort, Douglass works to persuade his comrades to adopt escape as their aim: "I did my very best to imbue the minds of my dear friends with my own views and feelings. ${ }^{" 69}$ And indeed Douglass sees his intervention as necessary for cultivating a commitment to attempt escape: "Not one of them was self-moved in the matter. They all wanted to be free; but the serious thought of running away, had not entered into their minds, until I won them to the ${ }^{69}$ Douglass, 168. 
undertaking." ${ }^{, 70}$ But, crucially, Douglass characterizes his efforts as a victory (he 'won' them over); he goes on in the same passage to characterize himself as an "instigator." Douglass's aim in these organizing conversations is not to channel his own will through his co-conspirators actions, but to animate their wills in pursuit of a commitment to freedom that they themselves come to adopt. Indeed, the forcefulness of Douglass's persuasion implies a humble appreciation of the efforts required to stir others to action on the basis of their own political judgment: Douglass moves, rather than manipulates, his co-conspirators to action. The picture of winning over his peers, instigating them to political action, expresses an appreciation of their standing as distinct political actors who exercise their own judgment and agency in action in concert with Douglass. In taking a humble orientation towards his co-conspirators, Douglass sees them as agents with whom he must cultivate bonds of love, trust, loyalty, solidarity, and non-paternalism. This centrally involves a humble recognition that what is in the best interest of his coconspirators cannot simply be discovered (so that Douglass could discern it for them), but that it must be expressed through his co-conspirators' exercise of their own judgment and agency.

Advocacy for humility in political life thus does not entail advocacy for docility or quietism. A humble acknowledgment of others as free and equal political agents motivates robust political engagement, in order to animate others to action on the basis of what they come to judge as in their own interest. The known and being known of emancipated political life, on this picture, is not a matter of discovering what we value and bringing it about in the world. It is instead a matter of forging bonds of love, trust, loyalty, solidarity, and non-paternalism in part by forming judgments of shared interests in concert with, rather than on behalf of, one another. This is not to say that anything goes in judging what is in one's own interest: good political judgment must be responsive not only to one's agency, but also to other persons and the world. It is to say that we forge what matters in political life in dialogue and struggle with others. Humble

\footnotetext{
${ }^{70}$ Douglass, 171.
} 
recognition of the limits of one's own agency is, in this way, hopeful recognition of our collective power to remake ourselves, and in so doing, our shared world. 